Peer-reviewed

\title{
The Internationalization of Conflicts: Theoretical Background, Conceptualization, and Contemporary Middle- East Region
}

\author{
Internacionalizace konfliktů: Teoretické pozadí, \\ konceptualizace a oblast současného Středního východu
}

\section{Josef Kraus}

Abstract: This article deals with the research of the internationalization of conflicts, trying to examine this phenomenon from the theoretical perspective and as a definition. Then the term of internationalization of conflict is conceptualized in order to be applied to a chosen internationalized internal armed conflict. The text also deals with various actors intervening in the internationalized conflict. They are divided into external and internal actors, while their interventions during civil war can be multilateral or unilateral. The concept of the conflict internationalization is also compared with the concept of the proxy war. The closeness of both terms can be confusing for many researchers and their division is one of the important outcomes of this article. At the end, two case studies of Syrian and Yemeni civil wars are introduced to the reader in the framework of the conflict internationalization concept.

Abstrakt: $\quad$ Tento text se zabývá výzkumem internacionalizace konfliktů, přičemž se snaží tento fenomén rozebrat po teoretické a definiční stránce, a následně jej konceptualizovat tak, aby bylo možné tento koncept využít pro výzkum vybraného konfliktu s mezinárodním přesahem. Text rovněž pracuje s různými druhy aktérů, kteří se do internacionalizovaného konfliktu zapojují. Rozlišuje především aktéry externí a interní, stejně jako intervence $v$ konfliktu $z$ jejich strany může být unilaterální či multilaterální. Uvedený koncept internacionalizace konfliktu je pak vymezen i vưči jinému blízkému konceptu tzv. zástupné války. Na závěr jsou uvedeny reálie dvou internacionalizovaných konfliktů na Středním východě - syrská a jemenská občanská válka.

Keywords: Armed Conflict; Internationalization; Proxy War; Conceptualization; State And Non-State Actors; Civil War.

Klíčová slova: Ozbrojený konflikt; internacionalizace; zástupná válka; konceptualizace; státní a nestátní aktéři; občanská válka. 


\section{INTRODUCTION}

The internationalization of conflicts has been a hot topic for the last couple of years. Many current civil wars have been internationalized due to foreign actors' interventions and many of those conflicts have been spread to (not only) a neighbouring country due to those interventions. A typical example of such a conflict is the currently ongoing civil war in Syria attracting not only local regional powers, such as Turkey, Saudi Arabia, and Iran, but also the global powers Russia and United States. The originally internal Syrian conflict has overflown into neighbouring Iraq and had a negative impact all other neighbouring states by the flood of war refugees. The intervention of the Gulf Cooperation Council armed forces led by Saudi Arabia into Yemeni civil war and Iranian support of Zaidiyyah Shi'as and chosen Yemeni tribes caused a huge disturbance in the Persian Gulf region and led to a situation called by some security experts a Saudi-Iranian proxy war. That is why the definition and conceptualization of the conflict internationalization are so important for current conflict researchers and security experts and analysts. The following text should create a background for resulting case studies of nowadays internal armed conflict not only in the region of Middle-East. The text itself has no ambition of bringing new scientific findings and extending knowledge, rather, it is a general survey of the examined phenomenon to be developed and researched in case studies by social sciences. At the beginning, there is a short introduction to related literature followed by the conceptualization of the chosen concept based on the most relevant sources. The emphasis is put on precise introduction to the terminology and conceptualization, that is why there are many exact quotations in the article. The main goal is to analyse available scientific literature and introduce it to the reader in the first part of the text, while the second part is a demonstration of the conflict internationalization concept based on a current hot conflict in the Middle-East. From this perspective, it seems redundant to the author to include any specific methodology, as the text has is more a survey rather than a scientific research.

\section{THE CONCEPT OF CONFLICT INTERNATIONALIZATION}

The concept of the conflict internationalization is not as wide-spread as many other concepts within security studies, thus, the spectrum of concepts, definitions, and terminology is rather limited. Nevertheless, there are some theoretical studies and many case studies dealing with the topic of an internal conflict spill-over, interference of external actors, proxy war, etc. There are also many perspectives on how to deal with this topic - those of political science, security studies, international law, or humanitarian. A connection between an ethnic conflict and its internationalization was created in the classic book by K. M. De Silva, Ronald James May in 1991 called "Internationalization of Ethnic 
Conflict"1 followed by a trio of authors David Carment, Patrick James and Zeynep Taydas in their book "Who Intervenes? Ethnic Conflict and Interstate Crisis" $\mathbf{2}$ and many of their common articles published subsequently. The ethnicity as one factor inclinable to the conflict internationalization is also reflected in the complex work of Kenneth Christie (ed.) ${ }^{3}$ called "Ethnic, Conflict, Tribal Politics: A Global Perspective". But ethnicity does not have to be the only factor of the internal conflict growing into the internationalized conflict. Amy Freedman ${ }^{4}$ deals with a general internal conflict and its potential to become internationalized, and the edited book is one of the fundamental works on this topic explaining the internationalization of insurgencies, introducing concepts and theories, and focusing on chosen case studies about Iraq, Lebanon, Sierra Leone, and many others. With the concept of conflict internationalization, a typology of interfering actors is connected. A classic work in this field is the definition of the Uppsala Conflict Data Program. ${ }^{5}$ It divides actors according to the level of their involvement and way of their interference in an armed conflict. The main division is between primary and secondary parties. While primary parties are those directly involved in the conflict and having formed the incompatibility of warring parties' interests, secondary parties can be further divided into two types - warring and non-warring (internal or external). While a secondary warring party is one that enters a conflict with troops to support actively one of the sides in the conflict, a non-warring party (or secondary supporting party) provides support to a primary party, thus affecting the development of the conflict in a certain way. It is obvious that external actors in matters of the conflict internationalization can be both - primary and secondary parties, based on the way and level of engagement.

The internationalization can be easily defined as a process through which an explicit and conscious decision is made. The decision to involve international actors in any phase (hostilities or negotiation) of a domestic conflict. The alternative strategy or opposite way toward this action is to isolate the internal conflict and exclude any international actors, which is highly complicated in a globalized world with many interfering state and non-state actors. Sylvain Vité ${ }^{6}$ characterizes internationalization as an intervention by a third state in support of a non-governmental armed group opposed to state forces within an existing internal conflict. He points out that this fragmented application of international humanitarian law was implicitly favoured by the International Court of Justice in the case concerning military and paramilitary activities in and against Nicaragua: in its analysis of the conflict, the Court differentiated between, on the one hand, the conflict

1 De Silva, K. M. and May, R. J. 1991. Internationalization of Ethnic Conflict, Continuum International Publishing.

2 Carment, D., James, P. and Taydas, Z. 2006, Who Intervenes?: Ethnic Conflict and Interstate Crisis. Columbus: The Ohio State University Press.

3 Christie, K. 1998, Ethnic Conflict, Tribal Politics: A Global Perspective, Richmond: Curzon Press.

4 Freedman, A. (ed.) 2014, The Internationalization of Internal Conflicts-Threatening the State, London and New York: Routledge. ISBN13:978-0-415-50789-9

5 Uppsala Conflict Data Program, Definitions, available online at: http://www.pcr.uu.se/research/ucdp/ definitions/

6 Vité, S. 2009. Typology of armed conflicts in international humanitarian law: legal concepts and actual situations, International Review of the Red Cross, Volume 91 Number 873 March 2009. 
between the Nicaraguan government and the contras, and, on the other, the conflict between that same government and the government of the United States. From another perspective, Vité characterizes the internationalization of a conflict in the case that conflicts are not confined within the borders of a single state but concern two or more States.

Steward" brings a slightly different definition. According to him, the term "internationalized armed conflict" describes internal hostilities that are rendered international. The factual circumstances that can lead to internationalization are numerous and often complex: the term internationalized armed conflict includes war between two internal factions both of which are backed by different states, direct hostilities between two foreign states that militarily intervene in an internal armed conflict in support of opposing sides, and war involving a foreign intervention in support of an insurgent group fighting against an established government.

There is also a completely different point of view upon conflict internationalization. Not from the perspective of external interference, but from the perspective of movements of refugees and internally displaced people who escape abroad. It creates a threat to security of people in the countries that provide asylum. Albrecht Schnabel ${ }^{8}$ uses also other terms such as conflict spill-over or extension of the conflict. According to his research, the flow of forcibly displaced people influences the internal security of the receiving regions significantly. According to David Carmet, ${ }^{9}$ there are three existing theoretical approaches to the process of conflict internationalization: the theory of conflict extension, the theory of conflict interaction and human needs, and the theory of conflict transformation. The theory of conflict extension deals with the direct involvement of outside actors in the internal ethnic turmoil with a presupposed outside actor's self-interest in the conflict. This theory includes a factor of outside involvement, characterized by the extent to which the conflict is important to the international system. This argument presupposes a more extensive outside involvement in conflicts that are more important for influential outside actors. The theory of conflict interaction and human needs emphasizes internal ethnic conflict processes and describes the process of ethnic conflict internationalization through internal power seeking outside support. Leaders of various ethnic groups, fighting for power, call on the international community and supranational organizations, relying on human rights support, which lends a legitimacy to self-determination claims. The third theory, the conflict transformation theory is based on the assumption that conflict spill-over to the international level often occurs when a weak government cannot cope with internal ethnic, economic, social, and political problems. As a result, the governments look externally and make irredentist claims to the other

7 Steward, J. G. 2003, Towards a single definition of armed conflict in international humanitarian law: A critique of internationalized armed conflict, IRRC June 2003 Vol. 85 No 850.

8 Schnabel, A. 2002. Southeast European Security: Threats, Responses, Challenges, Nova Biomedical, ISBN: 978-1590330975, pp. 107-108

9 Carment, D. The Ethnic Dimension in World Politics: Theory, Policy and Early Warning, The World Quarterly, Vol. 15, No. 4, Winter 1994. 
states, in which respective minorities live. This strategy allows states to find an external scapegoat, project internal problems on it, and safeguard their own power and prestige.

However, for this article, we stay focused on the intervention of foreign actors into one state's business and then on an effect of one state's civil war on the neighbouring countries' internal security. There are two main types of internationalized internal armed conflict. First, one or more third states or international/regional organizations intervene in support of a state involved in an armed conflict against an organized armed group, or second, they intervene in support of an organized armed group involved in an armed conflict against a state. Also, the combination of these two types is possible. But the involvement of external actors can result in a different situation and phenomenon a proxy war. A proxy war can be defined as a war instigated by a major power which does not itself become involved or a conflict between two states or non-state actors when neither entity is directly engaged against the other.

\section{ACTORS OF CONFLICT INTERNATIONALIZATION}

From the actors' perspective, the decision to (or not to) internationalize can be made by both external and internal actors. In the first case, we can speak about regional hegemonic state or global power, in the second, local conflict parties, the state or non-state differentiation does not matter. According to Borda, ${ }^{10}$ the concept of internationalization moves along a continuum in which on one extreme, external actors such as powerful or neighbouring states, international organizations, and non-governmental organizations can decide to participate in a unilateral way. In this scenario, internationalization takes the form of interventions. On the other extreme of the continuum, parties to the conflict make this decision. They invite external actors at the same time (states, international organizations, NGOs, etc.) to participate in their own confrontation. In the same vein, on one extreme, international actors may decide not to take part or intervene in a certain internal conflict, and on the other, local parties can opt for blocking or avoiding international participation. For visualization, see the picture 1 below.

Why are local parties interested in attracting foreign actors to intervene in their domestic issues? Borda ${ }^{11}$ argues that parties to the conflict look for two fundamental assets when they internationalize their conflict: material resources to fight the war and international legitimacy. Material resources are usually connected to military support from abroad. Borda calls it military internationalization and characterizes it as the type of internationalization the parties to the conflict use in order to obtain external military or logistic support to fight the war and improve their military position vis-à-vis their

10 Borda, S. P. 2009. The Internationalization of Domestic Conflicts: A Comparative Study of Colombia, El Salvador and Guatemala, The Faculty of the Graduate School of the University of Minnesota, available at: https://goo.gl/ZHR8SX, p. 23

11 Ibid., p. 21 
opponents. For the second asset, according to Borda, parties to the conflict also attempt to gain legitimacy. The objective is to obtain political support for their cause: for the state, it means obtaining international approval for its right to govern and to fight threats against itself; for insurgent organizations, it means obtaining international support for their right to fight against what they consider an illegitimate state. Borda calls it political internationalization.

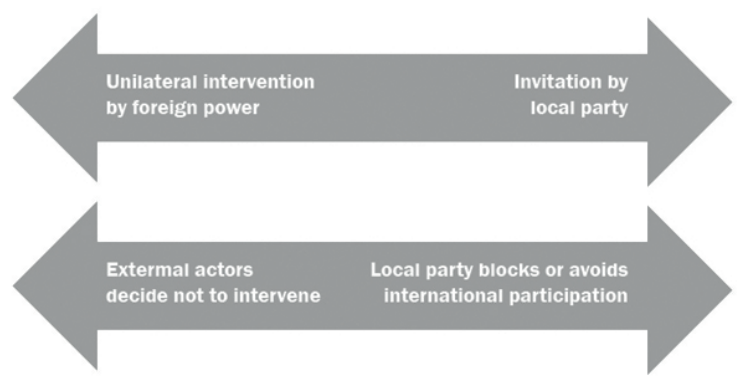

Picture 1: Axes of internationalization

Barnett and Levy ${ }^{12}$ believe that weak state rulers seek international support or cooperation to deal with local security, political or economic problems. Economic and political constraints on the state's mobilization of societal resources are, according to the authors, a powerful incentive to make alignment concessions to others in return for military support to deal with external threats to security and for economic support to deal with threats to the domestic political economy. Hence, Third World leaders might prefer alliances over internal extraction because political leaders are often tempted to try to secure the material resources necessary to deal with (internal) threats (by placating disgruntled social groups or by other means) through external alliance formation rather than through internal extraction from a society that is already economically stretched and politically alienated. That is, Third World states often form external alliances as a means of confronting internal threats.

Gleditsch et. al. ${ }^{13}$ see two types of interests of governments engaged in civil wars in the initiation of military action against neighbouring states. First, these governments may undertake cross-border counterinsurgency actions because rebels often seek out foreign sanctuaries or attempt to flee repression by slipping across borders. The second type occurs when states experiencing civil wars engage in retaliatory attacks against interventionist neighbours in the hope of coercing them into withdrawing support.

12 Barnett M, Levy J. S. 1991. Domestic Sources of Alliances and Alignments: The Case of Egypt, 1962-1973. International Organization, Volume 45, Issue 3 July 1991, pp. 369-395

13 Gleditsch KS, Salehyan I, Schultz K. 2008. Fighting at Home, Fighting Abroad: How Civil Wars Lead to International Disputes. The Journal of Conflict Resolution, Vol. 52, No. 4 (Aug., 2008), pp. 479-506 


\section{CONFLICT INTERNATIONALIZATION AND CONTEMPORARY MIDDLE-EAST REGION}

As mentioned above, there are two main interstate conflicts in the region of the Middle-East ${ }^{14}$ - the civil war in Syria affecting neighbouring Iraq and the civil war in Yemen. The first example is much more complicated and illustrates better the concept of conflict internationalization, while the second one is considered a proxy war by many security experts.

In the Syrian civil war, it is possible to identify three levels of conflict from the actors' perspective and two levels considering the internationalization - a world powers' intervention, a local powers' intervention, and local parties' conflict. The interstate conflict is fought by primary actors such as the standard Syrian army and the regime of president Bashar Assad on one side, with many non-state actors such as Free Syrian Army, Al-Nusra Front, the so-called Islamic State and many rebel groups on the other, plus Kurdish militias fighting in defence of their nation. The situation is much clearer in neighbouring Iraq where the standard Iraqi army along with the Shia militias and Kurdish Peshmerga forces fight the Islamic State. Focusing on the internationalization and the two mentioned levels, it is possible to name two world powers interfering in the Syrian conflict - the USA and the Russian Federation.

The American position toward the Syrian war has gone through many stages, but currently it can be described as military presence on the field (mainly special forces helping Kurdish militias fighting the IS), air strikes against both state and non-state actors (targeting Assad's installations and forces, chosen rebel groups and the IS) and broad support of pro-US or anti-IS rebel groups by lethal and non-lethal material. Russians in Syria are even more active through their military presence on the field and air campaign, both targeting non-state actors - anti-Assad rebel groups. Russia actively supports president Assad and fights Russia's own rebels from northern Caucasus in many Syrian Islamic militias.

From the perspective of the local powers' intervention, Turkey, Iran and Saudi Arabia must be mentioned first. All three external actors are highly active and their interest is contradictory to each other. Turkey supports chosen Syrian rebels, but also actively stands out against both - state and non-state local parties of the conflict. One of its main motivation for intervening in Syria is the regional rivalry with Iran. Iranian loss of an important ally of Bashar Assad means Turkey's gain in the whole territory. That is why Iran interferes a lot in the Syrian business on the side of Assad. The religious aspect (Syrian ruling family is from the Alawite sect of Shia Islam) is also important for Iran. Not in its competition with Turkey, but in the rivalry with Saudi Arabia. The Saudi Kingdom is an official part of the air campaign against the IS, but at the same time, it supports rebels (and mainly Sunni extremists) against Assad's regime.

14 Of course, considering the wider region of the Middle-East, we can also mention the civil war in Libya, but it is a bit further from the focus of this article. 
There are also many other foreign actors intervening in the Syrian conflict such as some European states (mainly the United Kingdom and France) originally supporting rebels, now being part of the anti-IS coalition and air campaign against it, or external non-state actors such as Lebanese Hezbollah serving Iranian interests and supporting president Bashar Assad by its own military presence in the Syrian territory. ${ }^{15}$ There are also states such as Lebanon or Jordan that are affected by the Syrian civil war but do not interfere extensively in it. They are mainly in the position of states accepting refugees and Schnabel (mentioned above) emphasizes their risk of internal security threat caused by migrants from abroad.

In the case of Yemen, the situation of internationalization is much clearer. However, the Yemeni civil war in the perspective of its local parties is indeed chaotic. Reasons for the Yemeni conflict are based on tribal, religious and political issues and the intervention of Saudi Arabia and Iran escalated the conflict into something, which is by many experts called a proxy war between those two regional rivals. Saudi Arabia, as a leader of the intervening coalition of Gulf Cooperation Council military forces, supports Sunnis and chosen tribes (the question is whether they are or are not state or non-state actors), runs the air campaign and field military operations against rival tribes and "Shias" (Zaidiyyah, Houthis) and, of course, tries to suppress the Iranian influence in the area. Compared to it, Iran supports its co-religionists and chosen tribes and tries to resist the Saudi military effort in Yemen from a distance. In contrast to the Saudi Kingdom, Iran is not participating in the armed conflict directly, so Iranian and Saudi forces are not involved in direct clashes at the Yemeni territory. The proxy war seems quite a reasonable label for such a conflict, although Saudi Arabia is present on the battlefield.

\section{CONCLUSION}

Conflict internationalization as described and defined above is a highly up-to-date concept for researching nowadays conflicts worldwide. Chosen examples of Syrian a Yemeni civil wars are just a short demonstration of an internationalized conflict complexity. The conceptualization of the examined phenomenon and the typology of actors can be easily applied to any internal conflict with the interference of foreign states and parties. This text presents the main conceptualization and theories usable for further studies and researches and better understanding of conflict internationalization. Although the concept of conflict internationalization is still not reflected so much in the expert community and security analysis, it is still necessary to pay attention to it, especially in the present time full of undeclared wars, conflicts spilling over into neighbouring areas and confrontations of regional or world powers.

15 For more information see Kraus, J. Islámský stát: aktéři konfliktu, jejich participace, motivy a cíle, Vojenské rozhledy, 2015, roč. 24 (56), no. 2, pp. 20-36, ISSN 2336-2995, available at: http://www.vojenskerozhledy. $\mathrm{cz} /$ kategorie/islamsky-stat-akteri-konfliktu-jejich-participace-motivy-a-cile 
Author: Josef Kraus, Ph.D., born in 1985. He graduated from the bachelor's, master's and doctoral studies in political science at the Faculty of Social Studies, Masaryk University. He still acts as a scientific researcher there. At the same time he also acts at the Centre for Security and Military Strategic Studies of the University of Defence in Brno. He is also in the editorial circle of professional online magazine Rexter. He deals with the security problems of the Middle East region, with a focus on Islamic Republic of Iran and State terrorism research.

How to cite:

KRAUS, Josef. The Internationalization of Conflicts. Vojenské rozhledy. 2017, 26 (5), 23-32. DOI: 10.3849/2336-2995.26.2017.05.023-032. ISSN 12103292 (print), 2336-2995 (on-line). Available at: www.vojenskerozhledy.cz 